\title{
Media Audiences in a Russian Province
}

\author{
Jukka PietiläInen
}

During the last 15 years of the 20th century, Russian society and media experienced a major change from a centrally planned, authoritarian and unified Soviet society to a market-based, (at least partly) democratic and fragmented society. With the collapse of the Soviet system, the former press structure with dominant national newspapers collapsed and regional newspapers became the most important part of the press. At the same time, newspaper publishing shifted from a daily (usually six times a week) to a weekly rhythm, so that in 2000 the circulation of weeklies was almost two thirds of the circulation of all newspapers (excluding newspapers published irregularly or less than once a week) (for these statistics see Pietiläinen 2002a, 124-125 and Pietiläinen 2002b, 213-217). According to many studies (Wyman 1997, 108; Resnyanskaya \& Fomicheva 1999, 87-88), newspapers have also been losing their readers in the post-Soviet period, but a major part of the population continues to read not only one but usually several newspapers.

Although press printing statistics do not reveal the complete picture of press plurality in individual regions, local studies reveal that the plurality of newspapers directed to a wider audience has increased significantly. For example, in Karelia the number of newspapers geared toward a wider audience increased significantly from two or three to over ten. However, few studies have paid attention to the regional newspapers in Karelia (Efremova 1999; Zhurnalist i zhurnalistika... 1994; Kirichek 1998; Lange 1997, 195; see also data from Russian GallupMedia revealing the same fact in many regions and a newspaper article by Kniivilä 2002) and usually the distribution of the audience among them has not been covered in these studies.

Department of Journalism and Mass Communication, University of Tampere, Kalevantie 4, FIN33014,jukka.pietilainen@uta.fi
The aim of this article is to illuminate the press competition in Karelia and to find out which factors have an impact on newspaper choice. The data is based on two surveys collected in the Republic of Karelia, the first one in February 2000 in Petrozavodsk and the second one in January-February 2002 in Petrozavodsk, Kondopoga and Pryazha (Prääsä). ${ }^{1}$

\section{The Media in Petrozavodsk and Karelia}

Petrozavodsk is the capital of the Republic of Karelia, one of the ethnic republics of the Russian Federation. It has 280,000 inhabitants, of which $81 \%$ are ethnic Russian, 5\% Karelian and 3\% Finnish. Petrozavodsk is a small regional centre in Northern Russia. The other part of Karelia is represented in this study by an industrial town, Kondopoga, and a rural district centre, Pryazha (Prääsä). Kondopoga is an industrial town with 36,000 inhabitants, of which $81 \%$ are Russians and $6 \%$ Karelians. The main industry is pulp and paper, including a mill that employs over a third of the working population of the city. Pryazha is a countryside municipal centre with 4,400 inhabitants, of which $49 \%$ are Russians and 35\% Karelians. Politically the citizens of Karelia support Eltsin and Putin. Of the political parties, Yabloko has had a strong position, but also communists and the LDPR have some activity. Currently, the "party of power", Unity or United Russia has a strong position

The newspapers of Petrozavodsk consist of two dailies: Severnyi Kurier (former CPSU organ Leninskaya pravda) and Reporter (founded in April 1999, closed in May 2000). In addition, two newspapers came out twice a week: Karjalan sanomat (a newspaper in Finnish; changed to weekly at the beginning of 2003) and Kareliya (the organ of the re- 
publican government; three times a week from January 2001). Finally, there were eight weekly newspapers; three popular papers (Guberniya, Petrozavodsk, TVR-Panorama); a non-partisan quality paper (Nablyudatel), a newspaper in the Karelian language (Ота mua); two partisan, political newspapers (Communist Leninskaya pravda and the populist, scandalous Nabat Severo-Zapada); and a youth paper (Molodezhnaya gazeta Karelii). In 2001 two new papers, Stolitsa and Vesti Karelii, were founded. Also some national newspapers have started regional editions in Karelia, e.g. Komsomolskaya pravda did so in March 2000 and Moskovskii Komsomolets in September 2002. In fall 2002 both Nablyudatel and Stolitsa were closed, which indicates perhaps a decline in the political financing of the press. Also Nabat Severo-Zapada has not been published regularly.

Kondopoga has two local newspapers: Avangard is published once a week by the local pulp and paper mill, while Novaya Kondopoga (New Kondopoga) is published by the city and district administration. The circulation of Avangard is 6,900 and that of Novaya Kondopoga 5,000 copies. In Pryazha the local paper Nasha zhizn (Our life) is published twice a week with four tabloid pages. The circulation of the paper is 2,500 copies.

A wide spectrum of radio and television channels is available both in cable and direct transmission in all these cities. Most of the channels are national or they cover several regions, while only a few are purely local. Moreover, some of the frequencies combine local and national programming.

\section{Media Audience in General}

The major part of the citizens of Petrozavodsk read newspapers regularly and the practice of reading several newspapers and following several media continues. In February 2002 almost half (42\%) of the audience followed newspapers, radio and television regularly and $76 \%$ followed all of them, at least irregularly. Those who did not follow all the media usually left aside either radio or newspapers.

Television, however, has become the most important type of media both due to the reach of its audience and as a source of information. Over $80 \%$ of the population watched television daily and only $4 \%$ did not watch it at all (Survey 2002). In Petrozavodsk watching TV was more regular than in Kondopoga and Pryazha. Many of those who did not watch television were over 50 and had only primary education, but among them were also many students and unemployed people. Only every fourth of them was working regularly and almost half of them did not read any newspapers at all.

The most popular television channels were ORT (Channel 1) (71\% regularly, 25\% irregularly), NTV (76\%, 16\%) and RTR (second channel) (66\%, $29 \%$ ). The majority also watched Karelian television, the TV-6 channel which broadcast also local programmes of the Petronet cable network and TV21 (Survey 2000). ORT and RTR were more popular among those with low and middle education, whereas those with higher education preferred NTV the most; also the young watched NTV more, while the old watched local Karelian television (on Channel 2) more often. Greater differences could be found in watching the cable television channels that the young watched more actively, while education caused no difference.

Interestingly, listening to radio was much less frequent: only $70 \%$ listened to radio daily and $17 \%$ did not listen to radio at all. Remarkably, many nonlisteners were in Kondopoga (20\%) and Pryazha $(23 \%)$. Non-listeners were often middle-aged (half of them were between 30 and 50) and rather highly educated and they followed other media almost as regularly as the population in general (Survey 2002). Age influenced the choice of the radio channel the most; the old listened to Radio Rossiya and Karelian radio, the young listened to new channels like Evropa Plyus. Foreign radio stations (without specification) were listened to by only $7 \%$ of the audience ( $2 \%$ regularly, $5 \%$ irregularly). Foreign radio stations had more listeners among those under 30 (Survey 2000).

\section{Trends in Newspaper Readership}

Over $70 \%$ of the audience read regularly at least one newspaper. Moreover, 25\% read at least one newspaper irregularly, but many of them were actually reading several newspapers. Only 5\% of the population did not read newspapers at all. Among the newspaper reading, the local newspapers were clearly the leaders. Only 17\% read national newspapers regularly and $49 \%$ irregularly while over one third did not read national newspapers at all in 2000. In 2002 the reading of national newspapers was even lower; only a bit half of the population were reading them. ${ }^{2}$

The way in which people get their newspapers in Karelia (as well as in other parts of Russia) differs dramatically from the Soviet era. In the Soviet Union, the people subscribed to newspapers and buying was only a complementary method of acquiring them. In post-Soviet Karelia, the newspaper 
audience mainly bought newspapers; $83 \%$ did so in 2002. Only $18 \%$ subscribed to newspapers; $31 \%$ read them at the homes of relatives and friends; $25 \%$ at work; a mere $12 \%$ read newspapers on bulletin boards, "stands" in Russian, which still exist; and only $8 \%$ read them in the library (Survey 2002).

The information about the number of subscribed copies of different newspapers indicates that Severnyi Kurier sells most of its print run in the form of subscriptions (about 65\%), while Kareliya gets only half and TVR-Panorama approximately $30 \%$ of its circulation in the form of subscriptions. For other new papers the figures are much lower: Guberniya 8\%, Nablyudatel 4\%, Petrozavodsk 3\%. ${ }^{3}$

Compared with other countries, the reading of newspapers at work in Russia was much lower than, e.g., in Sweden (in 1998 almost half, 48\%, of Swedes read newspapers at work or school) (Weibull 1999, 159). Those who read newspapers at work in Russia had higher education, worked often in administration and the service sector and were managers and professionals more often than workers.

The most popular newspapers were those that had the highest circulation. In Petrozavodsk the leaders were Guberniya and Petrozavodsk, both being read by over $60 \%$ of the respondents in both surveys. The third one was TVR-Panorama, which was read by the majority (57\%) of the respondents. The traditional daily, Severnyi Kurier, was read mainly irregularly by almost half of the respondents. The most popular national paper, Argumenty $i$ fakty, was read mainly irregularly and it seems that it lost popularity between 2000 and 2002. The new newspapers tend to gain popularity quite rapidly; hence Stolitsa was read at least irregularly by the majority of the population two years after the paper was founded and a few years earlier Guberniya became the most popular newspaper in two years. However, Stolitsa was closed in fall 2002, because it was no longer useful for the politically-minded financier. The paper had only a few subscribers and its wide readership may have existed due to its free distribution during the election campaign period.

The quality or elite papers: Kareliya, the organ of the local government, and the independent Nablyudatel, were read mainly by those who were especially interested in the press and who read many newspapers. They usually had higher education and were often managers and professionals. Kareliya was read most actively among the workers of state and local management and Nablyudatel among the workers of education.

The second most popular national paper, Komsomolskaya pravda, which started its local edition in April 2000, increased its popularity between 2000 and 2002. In February 2000 it was read in

Table 1. Reading of Main Newspapers in Petrozavodsk in 2000 and 2002

\begin{tabular}{|c|c|c|c|c|c|c|c|}
\hline \multirow[b]{2}{*}{ Guberniya } & \multirow{2}{*}{$\begin{array}{c}\begin{array}{c}\text { Founded } \\
\text { (closed) }\end{array} \\
1992\end{array}$} & \multirow{2}{*}{$\begin{array}{l}\text { Characterisation } \\
\text { of the paper } \\
\text { opposition, scandalous } \\
\text { weekly }\end{array}$} & \multirow{2}{*}{$\begin{array}{c}\begin{array}{c}\text { Circulation } \\
\text { in } 2002\end{array} \\
35000\end{array}$} & \multicolumn{2}{|c|}{$\begin{array}{c}\text { Regular reading/ } \\
\text { irregular reading } \\
2000, \%\end{array}$} & \multicolumn{2}{|c|}{$\begin{array}{c}\text { Regular reading/ } \\
\text { irregular reading } \\
2002, \%\end{array}$} \\
\hline & & & & 36 & 34 & 23 & 46 \\
\hline Petrozavodsk & 1990 & $\begin{array}{l}\text { city newspaper, colourful, } \\
\text { popular orientation }\end{array}$ & 12000 & 31 & 46 & 20 & 43 \\
\hline TVR-Panorama & 1990 & $\begin{array}{l}\text { apolitical weekly for the } \\
\text { whole family }\end{array}$ & 57000 & 25 & 32 & 19 & 38 \\
\hline Severnyi Kurier & 1918 & traditional daily & 14000 & 13 & 31 & 10 & 33 \\
\hline Argumenty i fakty & 1967 & national weekly & $\ldots$ & 12 & 46 & 7 & 29 \\
\hline Nablyudatel & $\begin{array}{l}1996- \\
2002\end{array}$ & quality, non-partisan weekly & 10000 & 6 & 25 & 7 & 29 \\
\hline Kareliya & 1992 & $\begin{array}{l}\text { organ of Karelian } \\
\text { administration }\end{array}$ & $4-7000$ & 7 & 18 & 5 & 28 \\
\hline Reporter & $\begin{array}{l}1999- \\
2000\end{array}$ & opposition daily & $\ldots$ & 6 & 24 & $\ldots$ & $\ldots$ \\
\hline $\begin{array}{l}\text { Molodezhnaya } \\
\text { gazeta }\end{array}$ & 1920 & traditional youth paper & 10000 & 2 & 12 & 3 & 16 \\
\hline $\begin{array}{l}\text { Komsomolskaya } \\
\text { pravda }\end{array}$ & 1920 & $\begin{array}{l}\text { national daily, local edition } \\
2000\end{array}$ & 10000 & 5 & 20 & 12 & 27 \\
\hline Stolitsa & $\begin{array}{c}2001- \\
2002\end{array}$ & $\begin{array}{l}\text { opposition weekly, short } \\
\text { news, colourful }\end{array}$ & $25-30000$ & $\ldots$ & $\ldots$ & 14 & 42 \\
\hline Vesti Karelii & 2001 & $\begin{array}{l}\text { St.Petersburg-managed } \\
\text { weekly, short news, colourful }\end{array}$ & 13000 & $\ldots$ & $\ldots$ & 10 & 25 \\
\hline
\end{tabular}


Petrozavodsk by a mere $25 \%$, while in 2002 the readership had grown to almost $40 \%$. Other national newspapers did not gain much popularity: Moskovskii komsomolets was read by 10\% (in 2000); other newspapers like Sovetskaya Rossiya, Nezavisimaya gazeta and Izvestiya got 5-7\%; and the others less than 5\%. The reading of minor national newspapers was mainly irregular.

The political newspapers Leninskaya pravda and Nabat Severo-Zapada were read only by around $10 \%$ of the population. The readers of these newspapers were older and more highly educated than people on average. The smaller newspapers included also papers for national minorities; for example, the Finnish Karjalan Sanomat and Karelian Ота тиа were read by one percent of the respondents (and by $10 \%$ of the Karelians of the survey) (Survey 2000). These papers were not included in the 2002 survey.

In Kondopoga $80 \%$ of the population read both the local newspapers (50\% regularly), and an additional $10 \%$ one of them (mainly Novaya Kondopoga), while $11 \%$ did not read local papers at all. Most of those who did not read local papers did not read any other papers. In Kondopoga the reading of Karelian or national papers was not very popular. Less than half of the population (44\%) read Karelian newspapers regularly and 35\% irregularly. The most popular Karelian papers in Kondopoga were TVR-Panorama (48\%), Guberniya (46\%) and Severnyi Kurier (37\%). Of the two most popular national papers, Argumenty i fakty was read by $43 \%$ and Komsomolskaya pravda by $35 \%$.

In Pryazha, the Petrozavodsk newspapers were more frequently read (63\% of the population read them regularly and 26\% irregularly) than in Kondopoga. The main newspaper is the local Nasha zhizn, which comes out three times a week with four pages in tabloid format. It was read regularly by $67 \%$ and irregularly by $22 \%$ of the population. The second in popularity was TVR-Panorama (40\% regularly, 30\% irregularly) and third Guberniya (23\% / 40\%). Of the other papers, only Severnyi Kurier was read by more than $50 \%$ of the population. In Pryazha, a smaller community, the tradition of subscribing to newspapers has remained stronger: $30 \%$ subscribed to newspapers. Also the subscription figures of the post confirm this: in Pryazha the number of subscribed newspapers per 1000 citizens is 166 , while in the centre of Petrozavodsk it is only 56.

In Pryazha the national newspapers were read as frequently as in Kondopoga and more frequently than in Petrozavodsk. Argumenty i fakty was read by $46 \%$ and Komsomolskaya pravda by $28 \%$.
Those who did not read Nasha zhizn did not read much at all, while those reading Nasha zhizn regularly read on average also five other newspapers. Non-readers of Nasha zhizn were mainly old, but not earning less than those reading irregularly. Despite its popularity, the small number of pages and mainly local content of Nasha zhizn did not appeal to readers much; only every sixth reader chose it as the first choice and TVR-Panorama was as popular. Many preferred also Guberniya, Severnyi Kurier and Argumenty i fakty, while one fourth did not prefer any of these or did not reply.

\section{Factors Influencing the Selection of Newspaper}

Age, education, social class and partly gender were the most important characteristics that divided the readership of different papers. Usually the newspaper reading increased with the age of the respondent but started to decrease earlier in the case of newer papers and later in the case of traditional papers (Table 2). The lowest newspaper reading was among old women. Among the major newspapers the readers of Severnyi Kurier were oldest (on average 44 years old) and the readers of Guberniya the youngest (40 years). Among all newspapers, the readers of Molodezhnaya gazeta were naturally the youngest (37 years). TVR-Panorama was read by women more often in all age groups except the oldest, but even among the oldest women TVR-Panorama was the most popular newspaper.

Also gender had some effect on newspaper choices. TVR-Panorama was read more actively by women, while Severnyi Kurier had slightly more readers among men. The differences caused by gender were rather minor and other newspapers were read equally by men and women.

The social group of the respondents caused also some differences in the reading of newspapers. Newspaper reading in general increased with social position, but some newspapers were read almost with the same frequency in all the social groups. It is important to notice that two groups, pensioners and students, are highly age-bound.

Table 3. Readers of Various Newspapers According to Social Group (both regular and irregular reading) in 2002. Social classes have been formed according to the criteria of Wright. Some small groups (self-employed, on maternity leave) excluded.

While there were no newspapers overwhelmingly read by workers, there were newspapers that the workers did not read often. These included Kareliya, Nablyudatel and Vesti Karelii and also 
Table 2. The Impact of Age and Gender on Reading Various Newspapers (2002 survey)

\begin{tabular}{|c|c|c|c|c|c|c|c|c|c|c|c|c|}
\hline \multirow{2}{*}{$\begin{array}{l}\text { Petrozavodsk } \\
\text { newspaper }\end{array}$} & \multicolumn{6}{|c|}{ Men } & \multicolumn{6}{|c|}{ Women } \\
\hline & $18-25$ & $26-35$ & $36-45$ & $46-55$ & $56-65$ & 66- & $18-25$ & $26-35$ & $36-45$ & $46-55$ & $56-65$ & 66- \\
\hline Guberniya & 52 & 62 & 71 & 54 & 53 & 45 & 59 & 62 & 69 & 68 & 55 & 40 \\
\hline Petrozavodsk & 37 & 43 & 41 & 44 & 42 & 41 & 47 & 41 & 49 & 48 & 41 & 32 \\
\hline TVR-Panorama & 39 & 51 & 58 & 50 & 53 & 59 & 53 & 62 & 63 & 65 & 63 & 44 \\
\hline Severnyi Kurier & 32 & 44 & 47 & 50 & 60 & 48 & 30 & 36 & 51 & 48 & 48 & 25 \\
\hline Stolitsa & 39 & 45 & 42 & 35 & 33 & 31 & 45 & 40 & 49 & 44 & 33 & 21 \\
\hline Nablyudatel & 21 & 27 & 26 & 25 & 28 & 35 & 21 & 29 & 32 & 37 & 29 & 19 \\
\hline Kareliya & 21 & 26 & 30 & 29 & 28 & 35 & 20 & 34 & 32 & 35 & 36 & 23 \\
\hline Vesti Karelii & 27 & 19 & 28 & 27 & 25 & 31 & 21 & 28 & 27 & 33 & 23 & 21 \\
\hline Molodezh. gazeta & 19 & 21 & 22 & 10 & 12 & 3 & 31 & 29 & 25 & 20 & 11 & 9 \\
\hline Argumenty i fakty & 36 & 49 & 44 & 31 & 32 & 14 & 38 & 52 & 45 & 51 & 29 & 19 \\
\hline $\begin{array}{l}\text { Komsomolskaya pravda } \\
\text { not reading any }\end{array}$ & 26 & 43 & 35 & 27 & 33 & 17 & 42 & 46 & 42 & 49 & 26 & 12 \\
\hline \multirow[t]{2}{*}{ of these papers } & 12 & 11 & 7 & 12 & 9 & 13 & 4 & 8 & 10 & 4 & 10 & 33 \\
\hline & \multicolumn{6}{|c|}{ Men } & \multicolumn{6}{|c|}{ Women } \\
\hline Newspaper & $18-25$ & $26-35$ & $36-45$ & $46-55$ & $56-65$ & $66-$ & $18-25$ & $26-35$ & $36-45$ & $46-55$ & $56-65$ & $66-$ \\
\hline $\begin{array}{l}\text { Avangard (only } \\
\text { Kondopoga) }\end{array}$ & 61 & 74 & 85 & 73 & 75 & 70 & 72 & 76 & 80 & 94 & 89 & 40 \\
\hline $\begin{array}{l}\text { Novaya Kondopoga } \\
\text { (only Kondopoga) }\end{array}$ & 71 & 79 & 94 & 81 & 88 & 80 & 86 & 91 & 97 & 91 & 85 & 53 \\
\hline $\begin{array}{l}\text { Nasha zhizn } \\
\text { (only Pryazha) }\end{array}$ & 89 & 82 & 86 & 100 & 80 & 80 & 93 & 91 & 95 & 100 & 86 & 75 \\
\hline
\end{tabular}

Stolitsa and Severnyi Kurier were read more often by managers than by workers. The unemployed were, in general, reading only the most popular newspapers and also among students reading was usually less frequent. It seems that the more local the papers were, the smaller the class differences in reading them were.
Also education had an impact. All the papers were read more actively by those with higher education, while some of the papers (TVR-Panorama, local papers) were read even by those with a lower level of education. The clearest impact of education was with Nablyudatel, which was read by less than $10 \%$ of those with low education and over $40 \%$ of

Table 3. Readers of Various Newspapers According to Social Group (both regular and irregular reading) in 2002. Social classes have been formed according to the criteria of Wright. Some small groups (self-employed, on maternity leave) excluded

\begin{tabular}{|c|c|c|c|c|c|c|c|}
\hline Newspaper & $\begin{array}{c}\text { Managers } \\
(67)\end{array}$ & $\begin{array}{c}\text { Middle } \\
\text { groups } \\
(104)\end{array}$ & $\begin{array}{l}\text { Professional } \\
\text { and skilled } \\
\text { workers } \\
(230)\end{array}$ & $\begin{array}{c}\text { Unskilled } \\
\text { workers } \\
(174)\end{array}$ & $\begin{array}{l}\text { Pens. } \\
(223)\end{array}$ & $\begin{array}{c}\text { Unemp. } \\
\text { (51) }\end{array}$ & $\begin{array}{c}\text { Students } \\
(74)\end{array}$ \\
\hline Guberniya & 81 & 80 & 67 & 57 & 47 & 39 & 51 \\
\hline Petrozavodsk & 64 & 53 & 48 & 40 & 35 & 18 & 44 \\
\hline TVR-Panorama & 72 & 64 & 60 & 62 & 51 & 33 & 42 \\
\hline Severnyi Kurier & 64 & 57 & 53 & 32 & 40 & 28 & 31 \\
\hline Stolitsa & 58 & 55 & 43 & 31 & 27 & 31 & 45 \\
\hline Nablyudatel & 42 & 42 & 37 & 17 & 24 & 14 & 14 \\
\hline Kareliya & 43 & 43 & 36 & 21 & 27 & 10 & 18 \\
\hline Vesti Karelii & 34 & 41 & 28 & 16 & 22 & 18 & 24 \\
\hline Argumenty i fakty & 58 & 61 & 53 & 34 & 20 & 14 & 35 \\
\hline Komsomolskaya pravda & 45 & 55 & 50 & 34 & 20 & 14 & 24 \\
\hline Avangard (only Kondopoga) & 84 & 85 & 84 & 77 & 75 & 48 & 61 \\
\hline Novaya Kondopoga (only K.) & 100 & 88 & 93 & 91 & 75 & 70 & 78 \\
\hline Nasha zhizn (only Pryazha) & 92 & 100 & 91 & 96 & 95 & 64 & 86 \\
\hline
\end{tabular}


those with higher education. Income had an impact similar to education. Those who earned more were usually more active readers of most newspapers. However, income had less impact on newspaper selection than education.

The comparison between the surveys of 2000 and 2002 indicates that the impact of age and gender seems to be declining while the role of education and social status seems to be increasing as factors influencing newspaper selection.

The comparison of the overlapping reading of newspapers indicates that the reading of unpopular newspapers is concentrated on those who read many newspapers and are interested in comparing them. On the other hand, the readers of the most popular newspapers are close to the average population also on the basis of their newspaper choices.

Factor analysis of the reading of various newspapers produced a result that newspaper reading in Karelia is structured mainly on the basis of two factors, elite (small audience) newspapers and popular (wide audience) newspapers. The first one of these factors explained $28.4 \%$ of the variance in 2000 (30.6\% in 2002) and the second one $14.4 \%$ (12.1 in 2002) (in Petrozavodsk only). Newspapers can be placed in a two-dimensional figure according to these factors. In Figure 1, the rotated factor points of these newspapers can be found on an almost direct diagonal, running from the top-left to the bottom-right corner, in other words, from the most popular or trivial to the most elite or serious news- paper. This structure of newspapers remained very similar both in 2000 and in 2002.

\section{Political Preferences and Newspaper Reading}

Also political preferences had some impact on newspaper choice. Supporters of Zyuganov read Leninskaya pravda significantly more often than supporters of other candidates. Severnyi Kurier was also read slightly more often by supporters of Zyuganov, but in this case the explaining factor was age: both those voting for Zyuganov and the readers of Severnyi Kurier were older than the population on average. The supporters of Yavlinskii read Severnyi Kurier and Kareliya less and chose more often Nablyudatel, Guberniya and Reporter.

The fact that Putin was an overwhelmingly popular candidate and that support for other candidates was a more conscious act was visible also in newspaper selection. The less popular newspapers were more popular among the supporters of the minor candidates (depending also on the political alignment of the newspaper): supporters of Yavlinskii were looking for alternative information in $\mathrm{Nab}$ lyudatel and Reporter, while supporters of Zyuganov did so with Leninskaya pravda.

In 2002 the survey was done before the local elections and then almost half of the respondents were unsure about their candidate preferences, while $60 \%$ of those who mentioned their candidate sup-

Figure 1. Presentation of Rotated Factor Points (varimax-rotation)

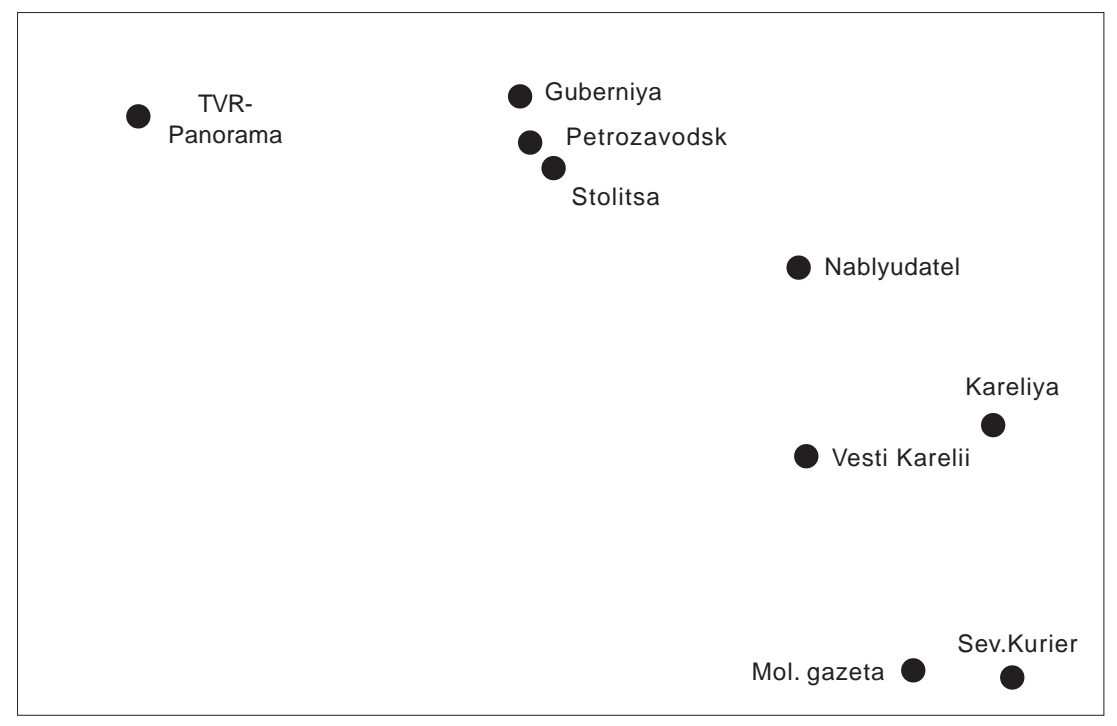


Table 4. Readers of Some Newspapers (both regular and irregular) Among Supporters of Various Presidential Candidates (February 2000 survey)

\begin{tabular}{|c|c|c|c|c|c|}
\hline Newspaper & $\begin{array}{l}\text { Putin } \\
(197)\end{array}$ & $\begin{array}{l}\text { Yavlinskii } \\
\quad(58)\end{array}$ & $\begin{array}{c}\text { Zyuganov } \\
\text { (48) }\end{array}$ & $\begin{array}{c}\text { Other candidate } \\
\text { (38) }\end{array}$ & $\begin{array}{c}\text { Against all, } \\
\text { will not vote } \\
(164)\end{array}$ \\
\hline Guberniya & 68 & 78 & 63 & 71 & 74 \\
\hline Petrozavodsk & 69 & 78 & 71 & 60 & 75 \\
\hline TVR-Panorama & 55 & 62 & 67 & 45 & 59 \\
\hline Severnyi Kurier & 45 & 36 & 52 & 47 & 46 \\
\hline Kareliya & 21 & 26 & 35 & 29 & 25 \\
\hline Nablyudatel & 26 & 48 & 31 & 18 & 36 \\
\hline Reporter & 28 & 41 & 29 & 26 & 27 \\
\hline Leninskaya pravda & 5 & 3 & 42 & 13 & 7 \\
\hline Nabat Severo-Zapada & 18 & 12 & 25 & 26 & 16 \\
\hline
\end{tabular}

ported the incumbent Sergei Katanandov. In the elections the incumbent Sergei Katanandov won in the first round. However, newspaper reading among the supporters of these candidates was more similar than in the presidential elections of 2000. For example, Guberniya was read only slightly more often (68\%-62\%) among non-supporters of Katanandov.

\section{Use of the Media and Views on Them}

On the different areas of newspaper content, the audience was the most interested in television programmes, city news, national political news and Karelian political news (only $12-24 \%$ did not follow news on these topics). Almost half of the population (49\%) followed also news on crimes and scandals and on local politics. The other topics were less popular: $42 \%$ did not follow economic news, $35 \%$ ignored news on foreign affairs, $57 \%$ did not follow news on sports, $49 \%$ did not read letters to the editor, and $39 \%$ did not read advertisements (Survey 2000).

The differences between population groups were rather small. Economic news interested people with higher education, in managerial positions, those who worked in administration, and their popularity increased with the increase of income. Criminal news and scandals interested older people and those employed in education, science and culture less frequently. Workers followed sports news more often.

A major change has occurred in the popularity of foreign news items that were among the most popular items in the Soviet Union (Mickiewicz 1981). In 2000 foreign news was read regularly by $30 \%$ of respondents and not at all by $35 \%$ of them. Foreign news was less popular among those below 30 and among service and trade sector workers. The decline of interest in foreign news could be explained by the decreased provision of foreign news, especially in newspapers, in which foreign news is currently reported mainly as various human-interest stories.

A question in the 2000 survey asked about sources of information by focusing on ten various topics. Television was overwhelmingly the most important source of information on these topics, on average to $51 \%$ of respondents, and it was especially important in receiving information about the situation in the Caucasus (85\%) and concerning national politics. Second-most important were newspapers (23\% on average), which were especially important in local affairs, local politics, economics, prices and available goods. The question was duplicated in 2002 and the results remained the same: television was clearly the most important source on international and national affairs, while newspapers were the most important source on Karelian and local issues.

In the survey of 2000 only $4 \%$ trusted in the media completely; $50 \%$ trusted partly and $18 \%$ did not trust in it at all, while $23 \%$ chose the alternative answer: I compare information from various sources. In 2002 the trust in Karelian and Russian media was asked about separately in connection with trust in other social institutions and individuals. In 2002 Karelian media got a bit more positive rating than the Russian media: $23 \%$ trusted partly or fully in the Russian media, while $30 \%$ trusted in the Karelian media. The media was trusted less than the Russian president and government, the Karelian leadership, the church, non-governmental organisations and the army, but more than the courts, the Russian parliament, the militia, entrepreneurs and banks.

Those who fully trusted the media were mainly with a low level of education, were old and had a 
small income. Those who did not trust were more often unemployed, workers in administration, or with high incomes, but also those who felt that their economic situation was very bad. This kind of a curve of distrust or dissatisfaction was found also in Soviet studies (see Mickiewicz 1981, 134-135).

In 2000 over one third $(36 \%)$ of respondents saw the role of the media as mainly negative, while $26 \%$ saw the media as more positive than negative and $24 \%$ saw it as overwhelmingly positive. In 2002 the number of those who had a negative opinion on the role of the media had declined to one fourth (26\%), while positive attitudes had slightly increased. The most positive opinions were among those who trusted the media completely and the most negative among those who did not trust it at all. Also media consumption had an influence: the more people read the newspapers, the more positive was the attitude they had towards the media. Actually the causality may work so that a negative attitude towards the media decreases the will to consume it.

The surveys verified the known fact that Russians support the control of the media. On the other hand, the support for direct censorship was not large: only every sixth or fifth (17\% in $2000,19 \%$ in 2002) was a supporter of censorship, $43 \%$ supported the idea of social control in the form of a council (37\% in 2002), while every fourth $(25 \%$ in both surveys) felt that no control was needed. Censorship was favoured mostly among those over 50 , managers and at both ends of the income pyramid. Those who opposed censorship were more often below 30, with higher education, managers, workers in administration, with a higher income and those who felt that their economic position was good. The idea of supervising councils was supported almost equally in all the population groups. Almost half of those who trusted the media completely saw no need for control, while those who did not trust were the most willing to support censorship. In Petrozavodsk both censorship and no need for control were favoured more frequently than in Kondopoga and Pryazha, where the support for supervising councils and no answers (especially in Pryazha) were more frequent. In comparison, the answers to the same question in Moscow in 2002 were divided practically equally into three groups, $28-30 \%$ belonging to each of them.

\section{Discussion}

The Russian media has preserved its audience in the post-Soviet period and it seems that it is getting its lost trust back. On the other hand, the number of those who prefer some form of control remains relatively high, although censorship is usually rejected.

The most important changes in comparison with the late Soviet period are, first, that newspaper reading has changed from the combined use of national and local newspapers to the overwhelming use of just the local. Second, television has become the most important medium and source of information, although newspapers have preserved importance on the local level. Third, the interests of the public have changed from foreign news to local news and national politics. Also non-political material is popular, as the popularity of non-political newspapers indicates.

A new kind of division of audiences is in formation. The importance of education and social class are increasing while the role of age, which was one of the main factors in 2000, is declining. The Russian audiences are relatively active, choosing the media they like and using the possibility to compare information between various media. Part of the audience is interested mainly in local affairs and chooses popular (tabloid) newspapers, another part reads both popular and quality newspapers and only a small part reads mostly quality newspapers. The new newspapers are often the most popular first among the youngest readers but they also seem to reach the older readers rapidly. On the other hand, the political financing and likely common free distribution of some newspapers may have a negative effect on the newspaper market as a whole.

The Russian model of newspaper readership is not (yet) a system close to the British press model, in which tabloids and quality newspapers are read by clearly different parts of the population (e.g. Sparks 1987; 1995; Chalaby 1998) but actually the current state of the press market is closer to the Finnish (Nordic) press model, in which the audiences of many newspapers do not vary a lot, but there are some newspapers for elite or specialised audiences. There are also differences in comparison with the Nordic model: there are more newspapers in Russia and the most popular newspapers are tabloids oriented towards scandals and entertaining (in contrast to the most popular newspapers in the Nordic countries). These papers are read by everybody without major class, age or education-based differences.

In post-Soviet Russia each locality is increasingly its own local market for newspapers. Although there are a few national newspapers hat have got significant popularity and several regional newspapers in each region, the popularity of local 
newspapers can only rarely be surpassed. The local newspapers are especially popular in small towns. In Petrozavodsk a similar newspaper is lacking

\section{Notes}

1. The data was collected as a quota sample that was adjusted on the basis of age and gender, corresponding with the population. The interviews of the first sample (508 respondents) were conducted in February 2000 and questions were only mediarelated. The second sample was collected in Petrozavodsk (500 respondents), Kondopoga (354) and Pryazha (150) in February and March 2002 and the questions were related also to social structure and ethnic attitudes.

2. This figure is actually based on the reading of only the two most popular national newspapers , but on the basis of the 2000 data, it could be expected that over $90 \%$ of those reading national newspapers read one of these two papers.

3. Actually the number of printed copies (print run) does not equal circulation because part of the print run remains unsold.

\section{References}

Chalaby, Jean K. (1998) The Invention of Journalism Houndmills: Macmillan.

Efremova, Svetlana Sergeevna (1999) Noveishaya istoriya regionalnoi pressy chernozemya (1985$1998 \mathrm{gg}$.) [Recent history of regional press in BlackEarth Region (1985-1998)]. Avtoreferat dissertatsii. Voronezh: Voronezhskii gosudarstvennii universitet.

GallupMedia (2001) www.gallupmedia.ru (newspaper reading surveys in various cities).

Kirishek, P. I. (1998) Sotsiologiya publitsistiki [Sociology of publishing]. Saransk: Izdatelstvo Mordovskogo Universiteta. (which is likely a rule in other larger cities as well), perhaps because of high competition and many available newspapers.

Kniivilä, Kalle (2002) Den ryska journalistikens heroiska tid är förbi. Ny Tid, 8.1.2002.

Lange, Yasha (1997) Media in the CIS. A study of the political, legislative and socio-economic framework. Düsseldorf: The European Institute for the Media.

Mickiewicz, Ellen (1981) Media and the Russian Public. New York: Praeger.

Pietiläinen, Jukka (2002a) The Regional Newspaper in Post-Soviet Russia. Society, Press and Journalism in the Republic of Karelia 1985-2001. Tampere University Press. Available at: http://acta.uta.fi/ pdf/951-44-5463-4.pdf

Pietiläinen, Jukka (2002b) Statistical Analysis of the Russian Newspapers. In Nordenstreng, Kaarle, Vartanova, Elena \& Zassoursky, Yassen (eds.) Russian Media Challenge (second printing). Helsinki: Kikimora, 206-217.

Resnyanskaya, L.L. \& Fomicheva, I. D. (1999) Gazeta dlya vsei Rossii [Newspaper for the whole Russia]. Moskva: MGU, Fakultet zhurnalistiki.

Sparks, Colin (1987) The readership of the British quality press. Media, Culture and Society 9:4, 427-455.

Sparks, Colin (1995) Concentration and Market Entry in the UK National Daily Press. European Journal of Communication 10:2, 179-206.

Weibull, Lennart (1999) Dagspress. In Carlsson, Ulla, Bucht, Catharina \& Facht, Ulrika (eds.) MedieSverige 1999/2000. Statistik och analys. Göteborg: Nordicom-Sverige, 121-144.

Wyman, Matthew (1997) Public Opinion in Postcommunist Russia. Houndmills \& London: Macmillan.

Zhurnalist $i$ zhurnalistika Rossiiskoi provintsii (1994) Moskva: Fond zashchity glasnosti. Shortened version published in English: Journalists and Journalism of Russian Province. Survey. Moscow: Glasnost Defence Foundation, 1994. 